\title{
Prevalence of white spot syndrome virus infection detected by one-step and nested PCR in selected tiger shrimp (Penaeus monodon) hatcheries
}

\author{
Farhana Ayub · Md. Yusuf Sarker · Md. Samsul Alam
}

Received: 22 April 2007/Accepted: 10 November 2007/Published online: 28 December 2007

(C) Springer Science+Business Media B.V. 2007

\begin{abstract}
White spot syndrome (WSS) is considered as a great threat to commercial farming of the tiger shrimp (Penaeus monodon). The causal agent of WSS is a DNA virus called white spot syndrome virus (WSSV). The prevalence of this dreadful virus infection has been studied in five randomly selected hatcheries located in the Cox's Bazar district of Bangladesh. Both one-step and nested polymerase chain reaction (PCR) involving two pairs of primers, namely, 146F1/146R1 and 146F2/146R2, amplifying the $1447 \mathrm{bp}$ and $941 \mathrm{bp}$ fragments, respectively, were conducted to detect the WSSV. Out of 60 randomly collected shrimps, $12(20 \%)$ were found to be positive by one-step PCR, while $18(30 \%)$ were found to be positive by nested PCR. The nested PCR was found to be much more sensitive than the one-step PCR. The shrimp specimens showing clinical signs of WSS were positive for WSSV by both one-step and nested PCR. Some of the apparently healthy samples were also found to be positive for WSSV by nested PCR. Among the two primer-pairs, the inner pair amplifying the $941 \mathrm{bp}$ fragment was more sensitive than the outer primer pair amplifying the $1447 \mathrm{bp}$ fragment when used in onestep PCR.
\end{abstract}

Keywords Detection - Nested PCR - Penaeus monodon · Prevalence · White spot syndrome virus

F. Ayub $\cdot$ Md. Y. Sarker - Md. S. Alam

Department of Fisheries Biology and Genetics, Bangladesh Agricultural University,

Mymensingh 2202, Bangladesh

Present Address:

F. Ayub

Bangladesh Fisheries Research Institute, Mymensingh 2201, Bangladesh

Md. S. Alam $(\square)$

Institute of Veterinary Medicine, University of Göttingen, Burckhardt Weg 2,

37077 Göttingen, Germany

e-mail: samsul_bau@yahoo.com 


$\begin{array}{ll}\text { Abbreviations } \\ \text { ng } & \text { Nanogram } \\ \text { pg } & \text { Picogram } \\ \text { PCR } & \text { Polymerase chain reaction } \\ \text { PL } & \text { Post larvae } \\ \text { WSS } & \text { White spot syndrome } \\ \text { WSSV } & \text { White spot syndrome virus }\end{array}$

\section{Introduction}

Viral diseases are threatening problems for the global shrimp culture industry. White spot syndrome (WSS) has resulted in heavy mortalities and consequent production losses to the shrimp culture industry in many countries in Asia and Latin America (Momoyama et al. 1994; Larkins 1995; Wongteerasupaya et al. 1995; Karunasagar et al. 1997) since 1992, when it was first reported in Taiwan (Chou et al. 1995). WSS is caused by an extremely virulent DNA virus popularly known as white spot syndrome virus (WSSV). It has a wide host range and targets various tissues (Chang et al. 1996; Lightner 1996; Lo et al. 1996a; Kou et al. 1998; Maeda et al. 1998; Hossain et al. 2001). The principal clinical sign of WSS is the appearance of white spots in the exoskeleton and epidermis of the diseased shrimp. Shrimps of all age groups and sizes, irrespective of sex (Peinado-Guevara and López-Meyer 2006), in all kinds of aquaculture systems, whether extensive, semi-intensive or intensive (Karunasagar et al. 1997), are affected by WSSV.

WSSV causes serious economic losses because massive mortality can result in total crop damage within 3-10 days under farming conditions (Lightner 1996). The best method of preventing loss has been to exclude the pathogen from the production system. Transfer from captured wild broodstocks to post larvae (PL) that are used to stock rearing ponds has been considered as one of the major routes of viral introduction. Therefore, the detection of viral infection either in the brooders before being used in the hatchery or PL before stocking could help avoid this problem. Polymerase chain reaction (PCR) is a powerful tool for the detection of viral pathogens in shrimp aquaculture. It has been used for WSSV detection in broodstock and PL for the investigation of WSSV transmission routes among different hosts and for epidemiological studies (Lo et al. 1996a, 1996b; Maeda et al. 1998; Sahul Hameed et al. 2005). One-step PCR (Takahashi et al. 1996) and nested (two-step) PCR methods have been described for WSSV and it is generally recognised that nested PCR amplification methods are more sensitive than one-step PCR methods (Lo et al. 1996b; Peinado-Guevara and López-Meyer 2006).

The Penaeid shrimp of Bangladesh is considered as a highly valued product and its production and export play a dominant role in the economy of Bangladesh. Among 36 marine shrimp species available in Bangladesh, the black tiger shrimp (Penaeus monodon) is cultured widely in the coastal ponds or ghers of the Cox's Bazar, Khulna, Bagherhat and Satkhira districts. The shrimp farming of Bangladesh had been considered as a lucrative industry until the occurrence of WSS in the country. WSS made its first appearance in southeastern Bangladesh in 1994 and an outbreak of the disease in cultured black tiger shrimp occurred in semi-intensive farms in Cox's Bazar, where it caused losses of 50-60\%. Later, the disease occurred in southwestern Bangladesh, where it severely affected smallscale farms practising low stocking density, resulting in great economic loss. The loss due to WSS from 21 farms in Bangladesh in 1994 was estimated to be US\$5 million (Larkins 
1995). Heavy economic loss due to WSSV infection can be effectively reduced if timely diagnosis is carried out regarding the condition of WSSV infection.

Data on the prevalence of viruses in broodstock are important for developing strategies for health management. In the case of WSSV, virus-positive broodstock may yield either virus-positive or virus-negative larvae, depending on the degree of infection (Lo et al. 1997). It would be important to know the level of infection in the broodstock, so that the risk of producing infected larvae could be assessed. We report here the prevalence of WSSV infection in the broodstock of five selected hatcheries of the Cox's Bazar region. In this study, we have also compared the efficiency of one-step and nested PCR methods in detecting the virus.

\section{Materials and methods}

Collection of experimental animals

Two types of samples were collected for the present study: selected sample and random sample. As selected samples, seven tiger shrimps ( $P$. monodon showing clinical symptoms of WSS were collected from the Niribili hatchery to test whether the PCR primers developed by Lo et al. (1996b) are also effective in detecting the Bangladesh strain of WSSV. As random samples, 60 shrimps were randomly collected from five different hatcheries (12 from each), namely, the S. Alam hatchery, Chingri Bangla hatchery, Saudia hatchery, Niribili hatchery and Bolaka hatchery of the Cox's Bazar district to study the prevalence of virus infection in this region.

A small piece of pleopod/uropod (approximately $500 \mathrm{mg}$ ) from each specimen was clipped aseptically using scissors and transferred to $1.5-\mathrm{ml}$ microfuge tubes containing 95\% ethanol and then brought to the laboratory of the Department of Fisheries Biology and Genetics, Faculty of Fisheries, Bangladesh Agricultural University, Mymensingh, Bangladesh. Finally, the samples were stored at $-20^{\circ} \mathrm{C}$ for future use.

\section{Extraction of DNA from shrimp tissue}

Approximately 30-40 mg of tissue (pleopod/uropod) from each collected sample was cut into small pieces with scissors, homogenised by a micro-tissue-grinder in a $1.5-\mathrm{ml}$ microfuge tube and the total DNA was extracted by Proteinase-K digestion, phenol:chloroform:isoamyl alcohol extraction and the ethanol precipitation method, as described by Islam and Alam (2004). The DNA quality was checked by electrophoresis in $1 \%$ agarose gel and quantified using a spectrophotometer (Spectronic ${ }^{\circledR}$ Genesis $^{\mathrm{TM}}$, Spectronic Instruments Inc., USA).

\section{Polymerase chain reaction}

The primer-pairs 146F1/146R1 and 146F2/146R2 developed from the sequence of a cloned WSSV Sal1 1,461 bp DNA fragment by Lo et al. (1996b) that amplifies 1447 bp and $941 \mathrm{bp}$ fragments, respectively, were used in the present study to amplify the WSSV DNA fragments. Another primer pair, 143F/145R, yielding a PCR product of $848 \mathrm{bp}$, derived from a highly conserved region of the $18 \mathrm{~S}$ rRNA sequence of decapods (Kim and Abele 
Table 1 Primer sequences used for the amplification of white spot syndrome virus (WSSV) and tiger shrimp DNA

\begin{tabular}{|c|c|c|c|}
\hline Primer name & Primer sequence $\left(5^{\prime}-3^{\prime}\right)$ & Size (bp) & Reference \\
\hline $146 \mathrm{~F} 1$ & $5^{\prime}$-ACT ACT AAC TTC AGC CTA TCT AG-3' & 1447 & (Lo et al. 1996b) \\
\hline 146R1 & $5^{\prime}$-TAA TGC GGG TGT AAT GTT CTT ACG A- $3^{\prime}$ & & \\
\hline $146 \mathrm{~F} 2$ & 5'-GTA ACT GCC CCT TCC ATC TCC A-3' & 941 & \\
\hline $146 \mathrm{R} 2$ & $5^{\prime}$-TAC GGC AGC TGC TGC ACC TTG T- $3^{\prime}$ & & \\
\hline $143 \mathrm{~F}$ & $\begin{array}{l}5^{\prime} \text {-TGC CTT ATC AGC TNT CGA TTG TAG-3' } \\
\text { (where N represents G, A, T or C) }\end{array}$ & 848 & $\begin{array}{l}\text { (Kim and Abele 1990; } \\
\text { Lo et al. 1996b) }\end{array}$ \\
\hline $145 \mathrm{R}$ & $5^{\prime}$-TTC AGN TTT GCA ACC ATA CTT CCC- $3^{\prime}$ & & \\
\hline
\end{tabular}

1990; Lo et al. 1996b) was used as a positive control to check the quality of the DNA extracted from shrimp samples and the PCR conditions used. The sequences of the three sets of primers are shown in Table 1 . The primers were synthesised and supplied by 1 st Base Company Ltd., Singapore.

One-step PCR for the diagnosis of WSSV

One-step PCR reactions were performed on each DNA sample in a 10- $\mu$ l reaction mixture containing $2 \mu \mathrm{l}$ of template DNA, $0.25 \mu \mathrm{M}$ of each primer, $0.25 \mathrm{mM}$ each of dATP, dCTP, dGTP and dTTP, 1 unit of Taq DNA polymerase (GENEI, Bengalore, India), $1 \times$ Taq polymerase buffer and $1.5 \mathrm{mM}$ of $\mathrm{MgCl}_{2}$. The PCR amplification was performed in a personal thermal cycler (OmmE, Hybaid, UK). The reaction mixture was preheated at $95^{\circ} \mathrm{C}$ for $3 \mathrm{~min}$ for initial denaturation, followed by 35 cycles comprising $1 \mathrm{~min}$ denaturation at $95^{\circ} \mathrm{C}, 1 \mathrm{~min}$ annealing at $55^{\circ} \mathrm{C}$ and 2 min elongation or extension at $72^{\circ} \mathrm{C}$. A final step of $5 \mathrm{~min}$ at $72^{\circ} \mathrm{C}$ followed the last cycle to allow complete extension of all of the amplified fragments.

\section{Nested PCR for the diagnosis of WSSV}

In nested PCR, the amplified products of the first step of PCR served as the template DNA for the second step of amplification. In this case, the first-step amplification was carried out by the outer primer pair 146F1/146R1 with the following cycle parameters: initial denaturation at $95^{\circ} \mathrm{C}$ for $3 \mathrm{~min}$, followed by 15 cycles of $95^{\circ} \mathrm{C}$ for $1 \mathrm{~min}$, annealing at $55^{\circ} \mathrm{C}$ for $1 \mathrm{~min}$ and elongation at $72^{\circ} \mathrm{C}$ for $2 \mathrm{~min}$ and a final extension at $72^{\circ} \mathrm{C}$ for $5 \mathrm{~min}$. After the completion of the first step, $10 \mu \mathrm{l}$ of the reaction mixture was added to another $10 \mu \mathrm{l}$ of standard PCR cocktail containing the inner primer pair 146F2/146R2, dNTPs, buffer and Taq DNA polymerase. The thermal profile and the number of cycles were the same as in one-step PCR.

Sensitivity analysis of one-step and nested PCR

The sensitivities of one-step and nested PCR were determined by using different concentrations of template DNA. Two previously analysed samples showing strong positive signs of WSSV infection from two different hatcheries (Bolaka hatchery and Niribili 
hatchery) were chosen to analyse the sensitivity of one-step and nested PCR. The DNA template of the chosen samples was first diluted from $50 \mathrm{ng} / \mu \mathrm{l}$ to $1.0 \mathrm{ng} / \mu \mathrm{l}, 0.5 \mathrm{ng} / \mu \mathrm{l}$, $0.25 \mathrm{ng} / \mu \mathrm{l}, 0.125 \mathrm{ng} / \mu \mathrm{l}, 62.5 \mathrm{pg} / \mu \mathrm{l}$ and $31.3 \mathrm{pg} / \mu \mathrm{l}$ and $20.8 \mathrm{pg} / \mu \mathrm{l}$. From each dilution, $2 \mu \mathrm{l}$ was used as the template for one-step PCR and first step of the nested PCR. In the second step of the nested PCR, the amplified product of the first step served as the template DNA.

Agarose gel electrophoresis and visualisation of the PCR product

After the completion of PCR, $2.5 \mu \mathrm{l}(5 \mu \mathrm{l}$ in the case of $20 \mu \mathrm{l}$ nested PCR) of loading dye ( $0.25 \%$ bromophenol blue, $0.25 \%$ xylene cyanol and $30 \%$ glycerol) was added to each PCR tube, mixed well, centrifuged briefly and then loaded into the wells of $1.4 \%$ agarose gel. DNA molecular weight markers ( $\lambda$ DNA HindIII digest and/or 100 bp DNA ladder) were loaded on either side of the gel. The gel was then observed on a UV transilluminator and photographed by the BioDoc-It ${ }^{\mathrm{TM}}$ system.

\section{Results}

Specificity analysis of WSSV primers

The specificity of both WSSV primer pairs was assessed using the extracted DNA template from a shrimp showing symptoms of WSS. The primer pairs 146F1/146R1 and 146F2/ 146R2 yielded the expected 1447 bp and 941 bp amplicons, respectively, which suggests that these primers can also amplify the Bangladesh strain of WSSV.

The prevalence of WSSV in samples collected from five different hatcheries of Cox's Bazar

The PCR profiles of selected and random shrimp specimens collected from five different hatcheries are presented in Figs. 1 and 2. All of the seven selected samples having clinical symptoms of WSS were found to be positive by both one-step and nested PCR. Among the 60 random samples $19.99 \pm 13.3 \%$ (SE) were found to be positive by one-step PCR, while $29.99 \pm 12.2 \%$ (SE) were found to be positive by nested PCR (Table 2). None of the samples of the S. Alam and Saudia hatcheries were found to be positive by one-step PCR. However, two shrimps from each of these hatcheries were proved to be positive by nested PCR (Fig. 1). Among 12 samples of the Chingri Bangla hatchery, none were positive by either one-step or nested PCR. Four of the 12 random samples of the Niribili hatchery were found to be positive by one-step PCR, while six were found to be positive by nested PCR. All of the positive samples again were positive with both outer (146F1/146R1) and inner (146F2/146R2) primer pairs in the one-step PCR (Fig. 1). Eight specimens of the Bolaka hatchery were found to be positive by both one-step PCR (Fig. 2) and nested PCR (Table 2).

Sensitivity analysis of one-step and nested PCR

A relationship was observed between the concentration of the template DNA and the PCR signal in the one-step PCR, where the PCR signals became fainter with increased dilution 


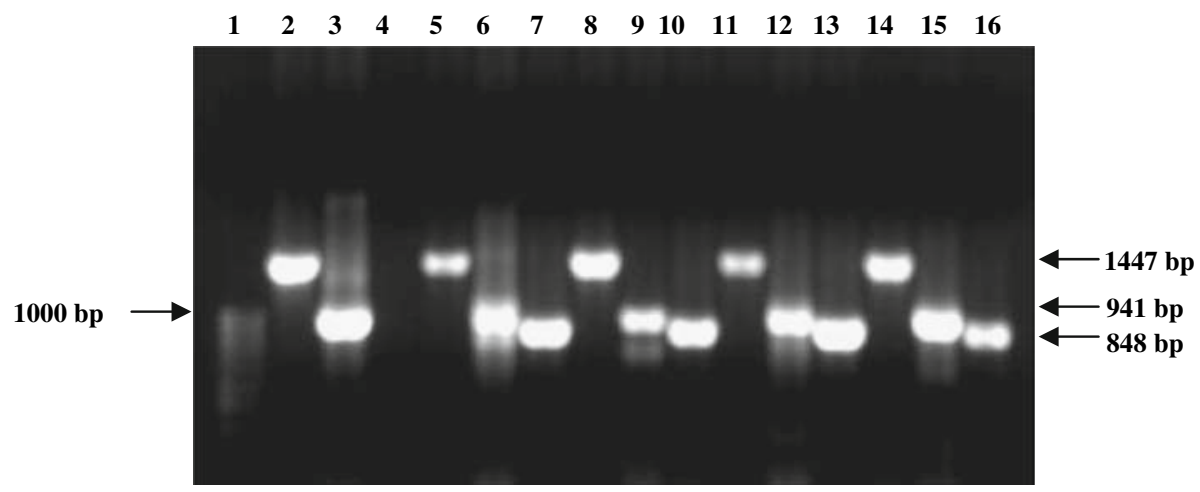

Fig. 1 Detection of white spot syndrome virus (WSSV) in Penaeus monodon collected from the Bolaka and Niribili hatcheries by one-step polymerase chain reaction (PCR) with primer pairs 146F1/146R1 (lanes: 2, 5, $8,11,14$ ) and 146F2/145R2 (lanes: $3,6,9,12,15)$. The $143 \mathrm{~F} / 145 \mathrm{R}$ primer pair was used to check the quality of the DNA and the reproducibility of the PCR technique (lanes: 7, 10, 13, 16). Lanes 2-13 represent the DNA template of WSSV-infected shrimp of the Bolaka hatchery (lane 4 contained no DNA template); lanes 14-16 represent the DNA template of WSSV-infected shrimp of the Niribili hatchery. Lane 1: molecular weight marker (100 bp DNA ladder)

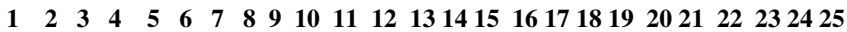

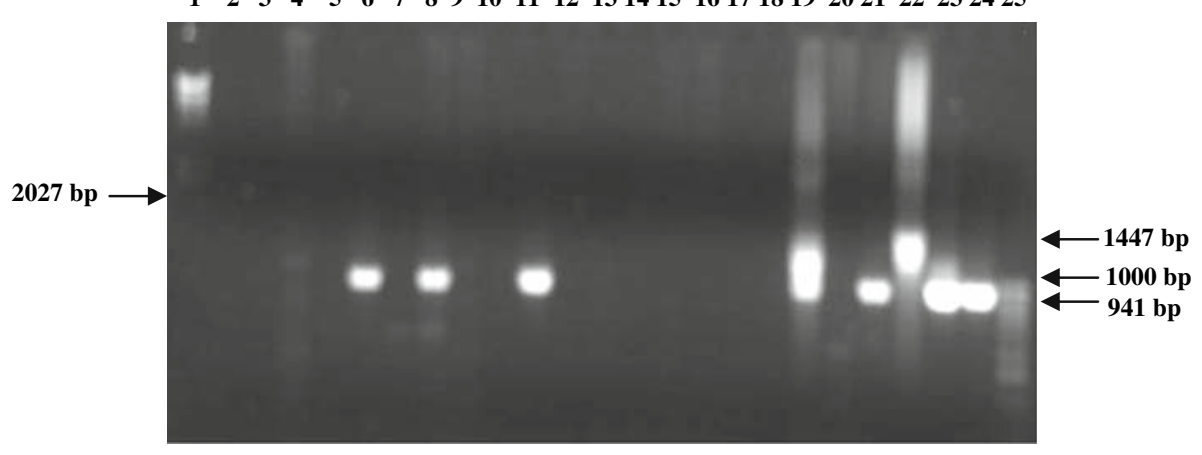

Fig. 2 Detection of WSSV in P. monodon collected from the S. Alam hatchery, Saudia hatchery, Chingri Bangla hatchery and Niribili hatchery by nested PCR. Lanes 2-7 represent the DNA templates of WSSVinfected shrimp of the S. Alam hatchery; lanes 8-14 represent the DNA template of WSSV-infected shrimps of the Saudia hatchery; lanes 15-18 represent the DNA templates of WSSV-infected shrimps of the Chingri Bangla hatchery; lanes 19-22 represent the DNA templates of WSSV-infected shrimps of the Niribili hatchery; lanes 23-24 represent the DNA templates of WSSV-infected shrimps of the Bolaka hatchery. Lane 1: molecular weight marker ( $\lambda$ DNA HindIII digest). Lane 25: molecular weight marker (100 bp DNA ladder)

of the template DNA and vice-versa. In the case of nested PCR however, the PCR signals were more or less similar up to certain dilutions of the template DNA (Fig. 3). In the case of the Bolaka hatchery sample, 41.6 pg templates DNA showed very weak positive signal and the sample of the Niribili hatchery showed negative sign at a template content of $0.50 \mathrm{ng}$ in one-step PCR. In the case of nested PCR, both samples showed a clear positive signal of WSSV infection, even at a $41.6 \mathrm{pg}$ template content (Fig. 3). Then, the sample of the Bolaka hatchery was chosen to analyse the sensitivity of non-nested PCR with outer and inner primer pairs and, for this purpose, $10 \mathrm{ng}$ to $31.2 \mathrm{pg}$ template DNA was used and 
Table 2 Prevalence of WSSV infection in random samples collected from five different tiger shrimp (P. monodon) hatcheries located in the Cox's Bazar region, Bangladesh

\begin{tabular}{|c|c|c|c|c|c|}
\hline \multirow{3}{*}{$\begin{array}{l}\text { Name of } \\
\text { hatchery }\end{array}$} & \multirow{3}{*}{$\begin{array}{l}\text { Sample } \\
\text { size }\end{array}$} & \multicolumn{4}{|c|}{ Prevalence of infection detected } \\
\hline & & \multicolumn{2}{|l|}{ One-step } & \multicolumn{2}{|l|}{ Nested } \\
\hline & & 146F1/146R1 & $146 \mathrm{~F} 2 / 146 \mathrm{R} 2$ & $\begin{array}{l}143 \mathrm{~F} / \\
145 \mathrm{R}\end{array}$ & $\begin{array}{l}\text { 146F1/146R1- } \\
\text { 146F2/146R2 }\end{array}$ \\
\hline S. Alam hatchery & 12 & $0(0.00)$ & $0(0.00)$ & 12 & $2(16.66)$ \\
\hline $\begin{array}{l}\text { Chingri Bangla } \\
\text { hatchery }\end{array}$ & 12 & $0(0.00)$ & $0(0.00)$ & 12 & $0(0.00)$ \\
\hline Saudia hatchery & 12 & $0(0.00)$ & $0(0.00)$ & 12 & $2(16.66)$ \\
\hline Niribili hatchery & 12 & $4(33.33)$ & $4(33.33)$ & 12 & $6(50.00)$ \\
\hline Bolaka hatchery & 12 & $8(66.66)$ & $8(66.66)$ & 12 & $8(66.66)$ \\
\hline Total no. $(\%)( \pm \mathrm{SE})$ & 60 & $12(19.99 \pm 13.3)$ & $12(19.99 \pm 13.3)$ & $60(100 \%)$ & $18(29.99 \pm 12.25)$ \\
\hline
\end{tabular}
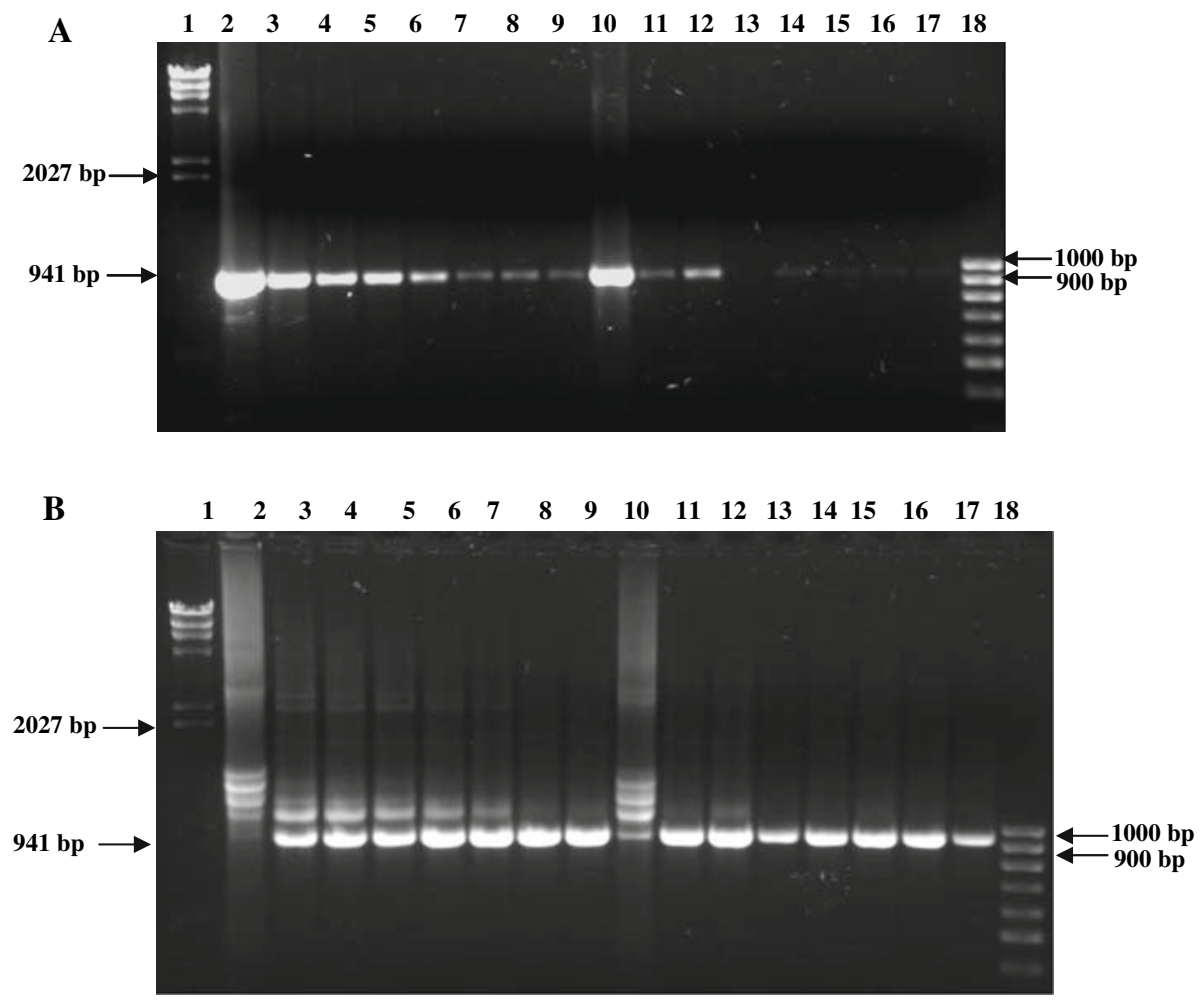

Fig. 3 Sensitivity analysis of PCR. (a) One-step PCR reaction. (b) Nested PCR. Lanes 2-9 represent serial dilutions of a positive sample of the Bolaka hatchery and lanes 10-17 represent serial dilutions of a positive sample of the Niribili hatchery. Template DNA concentrations: lanes 2 and 10, $100 \mathrm{ng} ; 3$ and 11, 2 ng; 4 and 12, $1.0 \mathrm{ng} ; 5$ and 13, $0.5 \mathrm{ng} ; 6$ and 14, $0.25 \mathrm{ng} ; 7$ and 15, $0.125 \mathrm{ng} ; 8$ and 16, $62.5 \mathrm{pg}$; and 9 and 17, $42 \mathrm{pg}$. Lane 1: molecular weight marker ( $\lambda$ DNA HindIII digest). Lane 18: molecular weight marker (100 bp DNA ladder) 


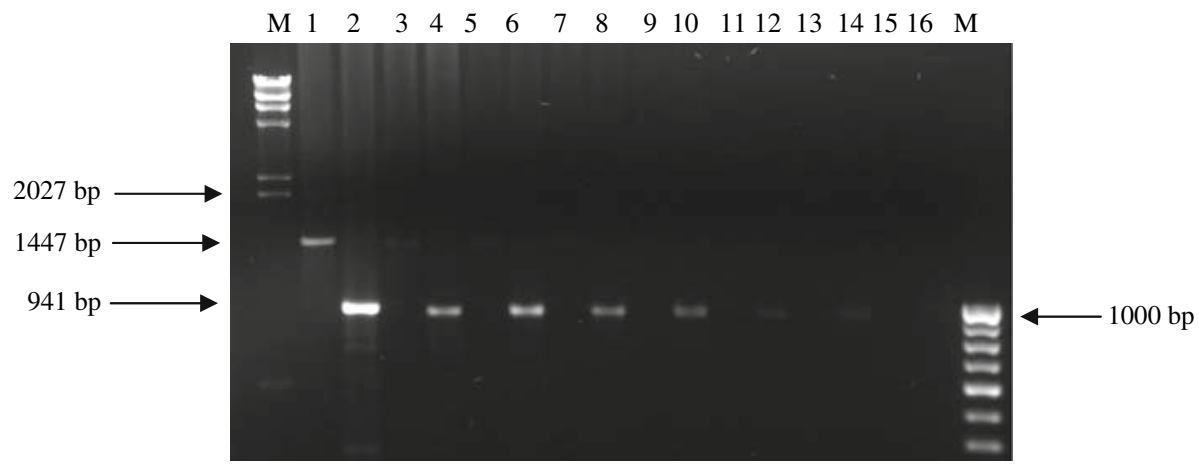

Fig. 4 Sensitivity analysis of one-step PCR with outer (1447 bp) and inner (941 bp) primer pairs using the Bolaka hatchery sample DNA. Template DNA concentrations: lanes 2 and 3, $10 \mathrm{ng} ; 4$ and 5, $2.00 \mathrm{ng} ; 6$ and 7, $1.00 \mathrm{ng} ; 8$ and 9, $0.50 \mathrm{ng} ; 10$ and 11, $0.25 \mathrm{ng} ; 12$ and 13, $0.125 \mathrm{ng} ; 14$ and 15, $62.5 \mathrm{pg} ; 16$ and 17 , $31.3 \mathrm{pg}$. Lane 1: molecular weight marker ( $\lambda$ DNA HindIII digest). Lane 9: molecular weight marker (100 bp DNA ladder)

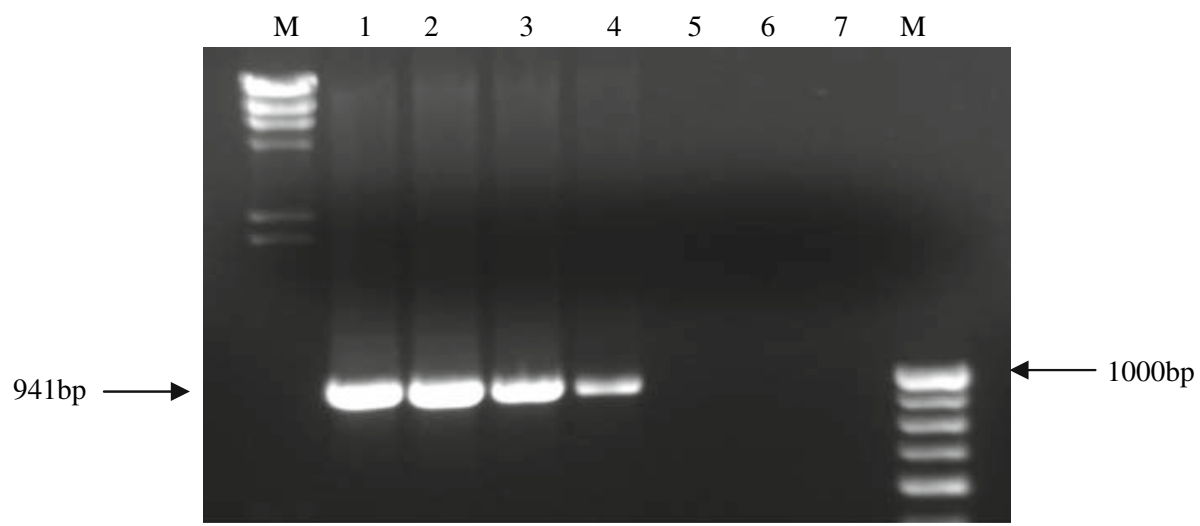

Fig. 5 Sensitivity analysis of nested PCR using the Niribili hatchery sample DNA. Template DNA concentrations: lanes 2, $0.25 \mathrm{ng} ; 3,0.125 \mathrm{ng} ; 4,62.5 \mathrm{pg} ; 5,31.3 \mathrm{pg} ; 6,15.6 \mathrm{pg} ; 7,7.8 \mathrm{pg} ; 8,3.9$ pg template DNA. Lane 1: molecular weight marker ( $\lambda$ DNA HindIII digest). Lane 9: molecular weight marker (100 bp DNA ladder)

we found that the outer primer pair (1447 bp) showed a negative signal at $1.00 \mathrm{ng}$, whereas the inner primer pair (941 bp) showed a negative signal at a $31.2 \mathrm{pg}$ concentration (Fig. 4). The other sample (Niribili hatchery) was further diluted up to $2.0 \mathrm{pg} / \mu \mathrm{l}$ and we found a negative signal at $15.6 \mathrm{pg}$ DNA content in the nested PCR reaction (Fig. 5).

\section{Discussion}

P. monodon is considered as one of the most important commercially cultured species in Bangladesh. P. monodon is the most susceptible host of WSSV (Wongteerasupaya et al. 1995). This species has been badly affected by WSSV in all of the shrimp-producing countries in Asia, including Bangladesh (Larkins 1995; Wongteerasupaya et al. 1995; 
Karunasagar et al. 1997). For definitive diagnosis and certification of the WSSV infection status of broodstock and fry, PCR technology has been recommended (OIE 2003). Molecular-based detection methods for shrimp viruses include normal PCR using degenerate primers (Chang et al. 1993) and nested PCR (Lo et al. 1996b; Belcher and Young 1998), among others. Due to higher sensitivity limits than most classical diagnostic methods, PCR has become the preferred method for the diagnosis of most shrimp viruses (Tang and Lightner 2000).

Natividad et al. (2006) tested both Philippine and Japanese WSSV isolates with primer pair 146F1/146R1 and found that the primer pair was able to amplify only the isolates from Japan but not the isolates from the Philippines. So, one of the objectives of the present study was to reveal whether the effectiveness of the primer sets 146F1/146R1 and 146F2/ 146R2 developed by Lo et al. (1996b) in Taiwan can also detect WSSV samples from Bangladesh. We found that both primer pairs were able to amplify expected size fragments from Bangladesh isolates of WSSV successfully.

We found that apparently healthy hatchery samples were positive for WSSV only by nested PCR, while the samples showing clinical signs of WSS were positive for WSSV by both one-step and nested PCR. However, apparently healthy samples of one hatchery were also found to be positive by one-step PCR. Those samples that were positive by one-step PCR were highly infected by WSSV and those that were positive only by nested PCR indicated a lower level of infection. A similar type of finding was also reported by Lo et al. (1996b). They revealed that the nested PCR technique allowed the gradation of viral infection, with highly infected animals being positive in non-nested PCR and lightly infected animals being positive only in nested PCR. The presence of WSSV can often be detected in apparently healthy PL by PCR (Lo et al. 1996b; Magbanua et al. 2000; Otta et al. 2003). Manivannan et al. (2002) reported that the PL samples from the affected tanks were positive for WSSV by one-step PCR, while those from the healthy tanks (not showing mortality) were positive only by nested PCR.

In our study, we used two pairs of primers designed by Lo et al. (1996b) containing $1447 \mathrm{bp}$ and $941 \mathrm{bp}$ amplicons specific for WSSV. It can be mentioned that the samples which were positive in one-step and nested PCR with primer pairs 146F1/146R1 and 146F2/146R2 were highly infected by WSSV. Again, we compared the sensitivity between two primer pairs and found that the primer pair amplifying $941 \mathrm{bp}$ was much more sensitive than the primer pair amplifying $1447 \mathrm{bp}$ (Fig. 4). Our result supports the views of Hossain et al. (2004), who reported that primers containing smaller amplicon size were much more sensitive than the primers containing larger amplicon size.

We also compared the sensitivity between one-step and nested PCR and, for that purpose, the same samples with the same dilutions were used and we found that nested PCR was much more sensitive than one-step PCR. Through a sensitivity analysis, we could optimise the PCR technique and the optimisation of PCR is necessary to assess the quality of a brood or PL stock. It would be important to know the level of infection in the brood stock, so that the risk of producing infected larvae could be assessed (Uma et al. 2005).

As mentioned earlier, we originally planned to validate whether the primers developed by Lo et al. (1996b) can also detect the WSSV strain infecting shrimps in Bangladesh hatcheries. Therefore, we collected seven samples with clinical signs of WSS from the Niribili hatchery. When we succeeded in detecting the virus in the infected shrimps by both one-step and nested PCR, we then collected some random samples (apparently healthy) from five hatcheries, including the Nirbili hatchery (Table 2). Our results of the initial detection of WSSV were validated in the PCR laboratory (Cox's Bazar) originally established by the ATDP (Agro-based Industries and Technology Development Project) 
funded by United States Agency for International Development (USAID), at present taken over by the Bangladesh Office of the WorldFish Center. They use a commercial WSSV detection kit manufactured by Farming IntelliGene Tech Corp., Taiwan, ROC. It is the only laboratory in Bangladesh where WSSV can be detected. Therefore, apart from this laboratory, there was no scope for inter-lab collaboration to validate the detection results. In the random samples, we found 30\% infection, which is lower compared to the $75 \%$ prevalence reported by Otta et al. (1999) from the west coast of India and also lower compared to the $39.4 \%$ prevalence reported by Uma et al. (2005) from the south coast of India.

We extracted DNA from infected/non-infected shrimp tissue for this study so that the templates contained DNA from shrimp as well as from the virus if the shrimp was infected. Therefore, it was not possible for us to obtain an estimate on the concentration of viral DNA. However, because of the high sensitivity of the nested PCR, it may be useful in confirming the early stages of WSSV infection when the virus concentration is relatively low or before the manifestation of infection. The determination of the exact viral load in shrimps at certain times of culture may be useful to predict either an outbreak of the WSSV disease or the completion of the culture (Peinado-Guevara and López-Meyer 2006). Apparently healthy samples may also carry the WSSV, which has been found to be positive mainly by the nested PCR method. Therefore, the samples that would be proved as negative by nested PCR may only be certified as non-infected. It is recommended to test the mother shrimps before use in the hatchery and representative samples of PLs by PCR before release into the ponds to avoid serious losses from WSS.

Acknowledgements The study was conducted under a research grant (no. 2005/14//AU) of the Bangladesh Agricultural University Research System (BAURES). This study was also partially supported by the Bangladesh Agricultural Research Council (BARC) under the core Research Programme. We are grateful to the hatchery owners who allowed us to collect the samples and Mr. Mohammad Anamul Kabir, PCR Lab of the ATDP (Agro-based Industries and Technology Development Project) at Cox's Bazar, who helped in validating some of our results by using the detection kit. We would like to thank Professor Sergio Marshall, Head of the Laboratory of Molecular Genetics and Immunology, Pontificia Universidad Catolica Valparaiso, Chile, for reading the manuscript and making necessary corrections.

\section{References}

Belcher CR, Young PR (1998) Colourimetric PCR-based detection of monodon baculovirus in whole Penaeus monodon postlarvae. J Virol Methods 74(1):21-29

Chang PS, Lo CF, Kou GH, Lu CC, Chen SN (1993) Purification and amplification of DNA from Penaeus monodon-type baculovirus (MBV). J Invert Pathol 62:116-120

Chang PS, Lo CF, Wang YC, Kou GH (1996) Identification of white spot syndrome associated baculovirus (WSBV) target organs in the shrimp Penaeus monodon by in situ hybridization. Dis Aquat Org 27:131-139

Chou HY, Huang CY, Wang CH, Chiang HC, Lo CF (1995) Pathogenecity of a baculovirus infection causing white spot syndrome in cultured penaeid shrimp in Taiwan. Dis Aquat Org 23:165-173

Hossain MS, Chakraborty A, Joseph B, Otta SK, Karunasagar I, Karunasagar I (2001) Detection of new hosts for white spot syndrome virus of shrimp using nested polymerase chain reaction. Aquaculture 198:1-11

Hossain MS, Otta SK, Chakraborty A, Sanath Kumar H, Karunasagar I, Karunasagar I (2004) Detection of WSSV in cultured shrimps, captured brooders, shrimp post larvae and water samples in Bangladesh by PCR using different primers. Aquaculture 237:59-71

Islam MS, Alam MS (2004) Randomly amplified polymorphic DNA analysis of four different populations of the Indian major carp, Labeo rohita (Hamilton). J Appl Ichthyol 20:407-412

Karunasagar I, Otta SK, Karunasagar I (1997) Histopathological and bacteriological study of white spot syndrome of Penaeus monodon along the west coast of India. Aquaculture 153:9-13 
Kim W, Abele LG (1990) Molecular phylogeny of selected decapod crustaceans based on 18s rRNA nucleotide sequences. J Crust Biol 10:1-13

Kou GH, Peng SE, Chiu YL, Lo CF (1998) Tissue distribution of white spot syndrome virus (WSSV) in shrimp and crabs. In: Flegel TW (ed) Advances in shrimp biotechnology. National Centre for Genetic Engineering and Biotechnology, Bangkok, Thailand, pp 267-271

Larkins PE (1995) Report on disease problems of cultured brackish water shrimp and freshwater prawns in Bangladesh, vol 1. Bangladesh Second Aquaculture Development Project. MOFL/DOF, Government of Bangladesh, $134 \mathrm{pp}$

Lightner DV (1996) A handbook of shrimp pathology and diagnostic procedures for diseases of cultured penaeid shrimp. World Aquaculture Society, Baton Rouge, Louisiana, $305 \mathrm{pp}$

Lo CF, Ho CH, Peng SE, Chen CH, Hsu HC, Chiu YL, Chang CF, Liu KF, Su MS, Wang CH, Kou GH (1996a) White spot syndrome baculovirus (WSBV) detected in cultured and captured shrimp, crabs and other arthropods. Dis Aquat Org 27:215-225

Lo CF, Leu JH, Ho CH, Chen CH, Peng SE, Chen YT, Chou CM, Yeh PY, Huang CJ, Chou HY, Wang CH, Kou GH (1996b) Detection of baculovirirus associated with white spot syndrome (WSBV) in penaeid shrimps using polymerase chain reaction. Dis Aquat Org 25:133-141

Lo CF, Ho CH, Chen CH, Liu K, Chiu YL, Yeh PY, Peng SE, Hsu HC, Liu HC, Chang CF, Su MS, Wang $\mathrm{CH}$, Kou GH (1997) Detection and tissue tropism of white spot syndrome baculovirus (WSBV) in captured brooders of Penaeus monodon with a special emphasis on reproductive organs. Dis Aquat Org 30:53-72

Maeda M, Itami T, Furumoto A, Hennig O, Imamura T, Kondo M, Hirono I, Aoki T, Takahashi Y (1998) Detection of penaeid rod-shaped DNA virus (PRDV) in wild-caught shrimp and other crustaceans. Fish Pathol 33(4):373-380

Magbanua FO, Natividad KT, Migo VP, Alfafara CG, de la Peña FO, Miranda RO, Alabaladejo JD, Nadala ECB Jr, Loh PC, Mahilum-Tapay L (2000) White spot syndrome virus (WSSV) in cultured Penaeus monodon in the Philippines. Dis Auat Org 42(1):77-82

Manivannan S, Otta SK, Karunasagar I, Karunasagar I (2002) Multiple viral infection in Penaeus monodon shrimp postlarvae in an Indian hatchery. Dis Aquat Org 48:233-236

Momoyama K, Hiraoka M, Nakano H, Koube H, Inouye K, Oseka N (1994) Mass mortalities of cultured kuruma shrimp, Penaeus japonicus, in Japan in 1993: histopathological study. Fish Pathol 29:141-148

Natividad KDT, Migo MVP, Albaladejo JD, Magbanua JPV, Nomura N, Matsumura M (2006) Simultaneous PCR detection of two shrimp viruses (WSSV and MBV) in postlarvae of Penaeus monodon in the Philippines. Aquaculture 257:142-149

OIE (2003) Manual of diagnostic tests for aquatic animals, 4th edn. Office International des Epizootics, Paris, France, $358 \mathrm{pp}$

Otta SK, Shuba G, Joseph B, Chakraborthy A, Karunasagar I, Karunasagar I (1999) Polymerase chain reaction (PCR) detection of white spot syndrome virus (WSSV) in cultured and wild crustaceans in India. Dis Aquat Org 38:67-70

Otta SK, Karunasagar I, Karunasagar I (2003) Detection of monodon baculovirus and white spot syndrome virus in apparently healthy Penaeus monodon postlarvae from India by polymerase chain reaction. Aquaculture 220:59-67

Peinado-Guevara LI, López-Meyer M (2006) Detailed monitoring of white spot syndrome virus (WSSV) in shrimp commercial ponds in Sinaloa, Mexico by nested PCR. Aquaculture 251:33-45

Sahul Hameed AS, Parameswaran V, Syed Mustaq S, Sudhakaran R, Balasubramanian G, Yoganandhan K (2005) A simple PCR procedure to detect white spot syndrome virus (WSSV) of shrimp, Penaeus monodon (Fabricious). Aquacult Int 13:441-450

Takahashi Y, Itami T, Maeda M, Suzuki N, Kasornchandra J, Supamattaya K, Khongradit R, Boonyaratpalin S, Kondo M, Kawai K, Kusuda R, Hirono I, Aoki T (1996) Polymerase chain reaction (PCR) amplification of bacilliform virus (RV-PJ) DNA in Penaeus japonicus Bate and systemic ectodermal and mesodermal baculovirus (SEMBV) DNA in Penaeus monodon Fabricius. J Fish Dis 19:399-403

Tang KFJ, Lightner DV (2000) Quantification of white spot syndrome virus DNA through a competitive polymerase chain reaction. Aquaculture 189(1-2):11-21

Uma A, Koteeswaran A, Indrani K, Iddya K (2005) Prevalence of white spot syndrome virus and monodon baculovirus in Penaeus monodon broodstock and postlarvae from hatcheries in southeast coast of India. Curr Sci 89:1619-1622

Wongteerasupaya C, Vickers JE, Sriurairatana S, Nash GL, Akarajamorn A, Boonsaeng V, Panyim S, Tassanakajon A, Withyachumnarkul B, Flegel TW (1995) A non-occluded, systemic baculovirus that occurs in cells of ectodermal and mesodermal origin and causes high mortality in the black tiger prawn Penaeus monodon. Dis Aquat Org 21:69-77 